\title{
Minimising endophyte contamination from ryegrass seed in cow dung
}

\author{
V.T. BURGGRAAF and E.R. THOM \\ Dexcel, Private Bag 3221, Hamilton \\ vicki.burggraaf@dexcel.co.nz
}

\begin{abstract}
Perennial ryegrass pastures in New Zealand are usually established from seed naturally infected with the wildtype endophyte. New pastures can now be sown with perennial ryegrass that has no endophyte or has been infected with a new endophyte. Cows can contaminate pastures by consuming ryegrass seed infected with the wild-type endophyte on old pastures, and transferring the seed in their dung onto new pastures. A quarantine period before grazing new pastures may allow cows to eliminate wild-type endophyte-infected perennial ryegrass seed from their digestive tract, preventing contamination from this source. A trial was run at Dexcel, Hamilton, to define an appropriate quarantine period. Cows grazed wild-type (high endophyte) ryegrass pastures containing seedheads for 4 days before grazing Lotus corniculatus (quarantine pasture) for a further 4 days. This procedure was repeated five times from November 2000 to April 2001. Dung samples were collected daily after shifting cows off high endophyte ryegrass. Pastures contained viable ryegrass seed on seedheads from December to April, and ryegrass seedlings germinated in dung samples collected from January to April. Viable endophyte-infected perennial ryegrass seed was present in dung for 2 days after removal from the seed source, with $0.8 \%$ of the seed eaten remaining viable. Ryegrass seed endophyte viability was reduced from $100 \%$ to $40 \%$ after passage through the digestive tract of the cows. It is recommended that cows do not graze endophyte-free pastures or those sown with ryegrass containing a new endophyte for at least 2 days after grazing high endophyte ryegrass pastures containing ryegrass seedheads.
\end{abstract}

Keywords: dairy cows, dung, perennial ryegrass, ryegrass endophyte, seedheads, seed transfer

\section{Introduction}

Perennial ryegrass on most New Zealand farms contains the wild-type endophyte (Neotyphodium lolii). This endophyte produces toxins which protects ryegrass against attack by insect pests such as Argentine stem weevil (Listronotus bonariensis) (Prestidge et al. 1982), but can also cause ryegrass staggers (Gallagher et al. 1981) in grazing animals. Previous work has shown that perennial ryegrass (Lolium perenne) seed, consumed when grazing seedheads over summer/autumn, can then germinate in dung after passage through dairy cows; the wild-type endophyte contained within this seed can also survive (van Vught \& Thom 1997). This poses a risk for pastures sown with endophyte-free or low endophyte ryegrass, and for pastures sown with ryegrass containing new endophytes (free of mammalian toxins), as they could become contaminated with ryegrass containing the potentially toxic wild-type endophyte. To be able to minimise contamination from this source, the time taken for viable endophyte-infected perennial ryegrass seeds to pass through the digestive tract of grazing animals must be determined.

Shelby \& Schmidt (1991) found that the passage of live tall fescue (Festuca arundinacea) seed through steers peaked 22 hours after feeding, and the last endophyteinfected seed was detected after 38 hours. In a study of sheep fed a mixture of perennial ryegrass seed and lucerne, $95 \%$ of viable endophyte-infected seed was voided within 32 hours of feeding, and less than $0.2 \%$ of the total seed eaten remained viable (Rolston et al. 2001). However, recovery of viable seed after passage through the digestive tract is affected by both the type of seed being fed and the species of animal it is fed to (Simao Neto et al. 1987). This is the first study of grazing dairy cows that provides an estimate of the time required for viable perennial ryegrass seed to pass through their digestive tract, and of the viability of the endophyte within this seed. Such information is essential to assess the full impact of seed transfer by animals on endophyte contamination of pastures.

\section{Methods}

\section{Trial design and grazing management}

The trial was conducted at Dexcel, Hamilton, from November 2000 to April 2001. Pastures were grazed in accordance with normal farm management preceding the experiment. Lactating Friesian dairy cows were grazed together for 4 days, before rotationally grazing two 0.25 ha high endophyte ryegrass (cv Vedette) paddocks for 4 days. Cows then grazed two 0.25 ha Lotus corniculatus paddocks over 4 days. During grazing of Lotus corniculatus, a $1 \mathrm{~m}$ border was fenced off inside the paddock to prevent cows from accessing ryegrass seedheads from adjoining paddocks. Cows were backfenced onto breaks so the date of deposition of dung pats could be easily defined. All pastures were fed ad libitum, and herd size ranged from 4 to 12 cows, depending on feed availability. This procedure was repeated five times, 
with the high endophyte paddocks being grazed from 912 November, 7-10 December, 18-21 January, 1-4 March and 29 March-1 April.

\section{Measurements}

\section{High endophyte ryegrass pastures}

The proportion of endophyte-infected ryegrass tillers (Hill et al. 1995) was determined in April 2000 by testing 20 randomly selected ryegrass tillers (cut at the base) per paddock. Ryegrass seedhead density was measured before and after each grazing in 30 randomly placed 0.12 $\mathrm{m}^{2}$ quadrats per paddock. These data were used to estimate the average number of ryegrass seedheads eaten per cow. Fifty ryegrass seedheads per paddock were randomly sampled the day before grazing. Seeds off these seedheads were germinated on potting mix in a shade house, and were regularly watered. The total number of seedlings that germinated were counted before testing for endophyte presence in a maximum of 50 ryegrass seedlings per paddock per grazing. Botanical composition was estimated pre-grazing from herbage samples cut to ground level. One sample per paddock was dissected into perennial ryegrass (seedhead + remainder), white clover, other grasses, weeds and dead matter.

\section{Lotus pastures}

Botanical composition was estimated pre-grazing from herbage samples cut to ground level. One sample per paddock was dissected into Lotus corniculatus, perennial ryegrass, white clover, other grasses, weeds and dead matter. After each of the 4 consecutive days of grazing Lotus corniculatus, samples of about $200 \mathrm{mls}$ from each new dung pat were bulked and mixed together. A $800 \mathrm{~g}$ subsample was then spread on potting mix to a maximum depth of $1 \mathrm{~cm}$, and was watered regularly. Germinating ryegrass seedlings were counted and tested for the presence of endophyte. Another $500 \mathrm{~g}$ subsample was used to check for the presence of ryegrass seed. The total output of viable ryegrass seeds per cow per day was estimated using a total faecal output of $28.6 \mathrm{~kg}$ dung/ cow/day (Marsh \& Campling 1970).

\section{Results \\ Botanical composition}

Ryegrass seedheads ranged from $9 \%$ (December) to $<1 \%$ (late March) of total dry matter in high endophyte ryegrass pastures. Total live ryegrass content dropped from 71 to $46 \%$ between December and January, being replaced by dead matter and hawksbeard.

The quarantine pastures had 50 to $83 \%$ Lotus corniculatus, up to $20 \%$ narrow-leaved plantain, and $20 \%$ white clover during the grazing periods. No ryegrass was present.

\section{Perennial ryegrass endophyte infection, seedhead density and viability}

Tillers in the high endophyte ryegrass paddocks were 90 and $100 \%$ endophyte-infected.

Seedhead densities peaked in mid-November, with an average of 356 ryegrass seedheads $/ \mathrm{m}^{2}$ (Figure 1). Numbers were similar in December, then declined

Figure 1 Pre-grazing perennial ryegrass seedhead density in high endophyte perennial ryegrass pastures (average of two paddocks) from November 2000 to March 2001. Error bars represent SEM.

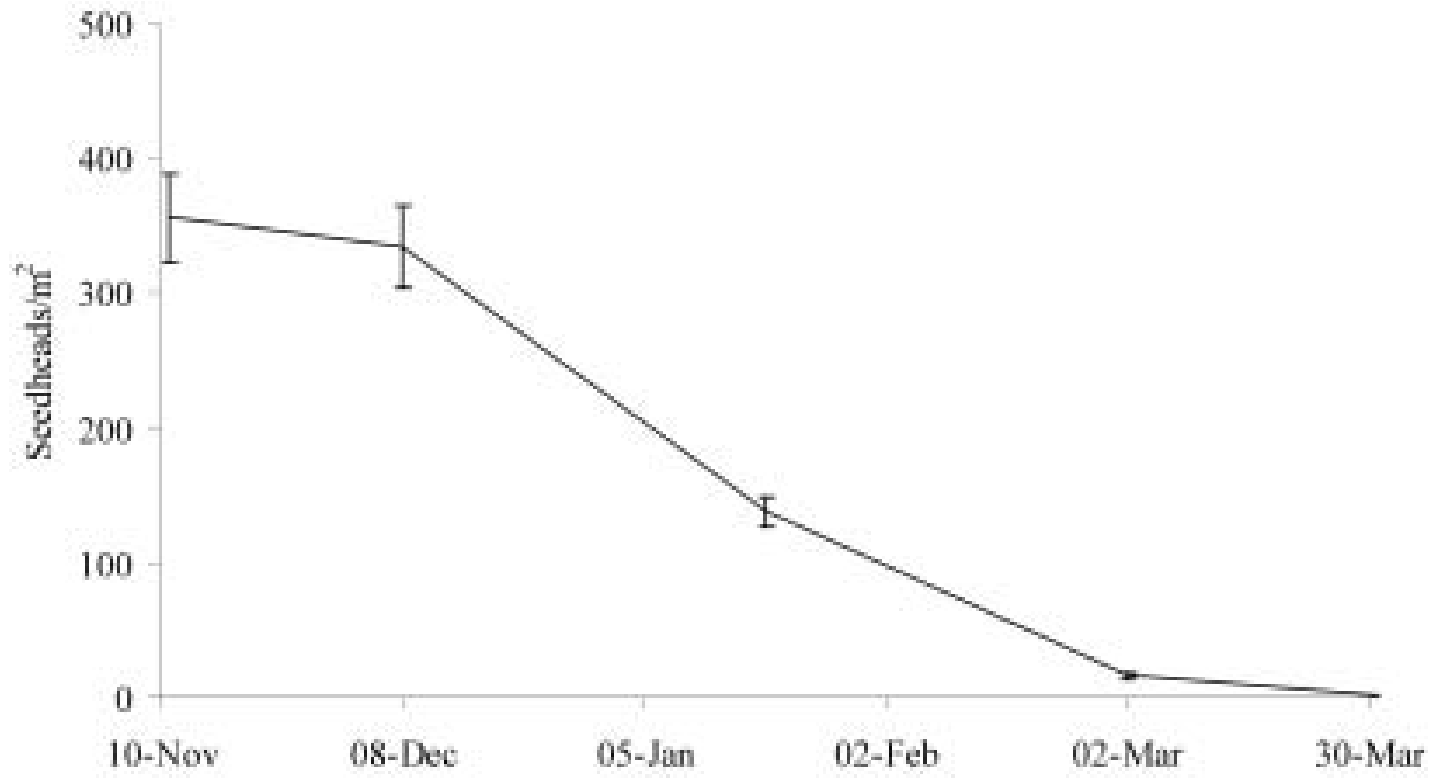


Figure 2 Pre-grazing density of viable perennial ryegrass seeds attached to seedheads in high endophyte ryegrass pastures (average of two paddocks) from November 2000 to March 2001.

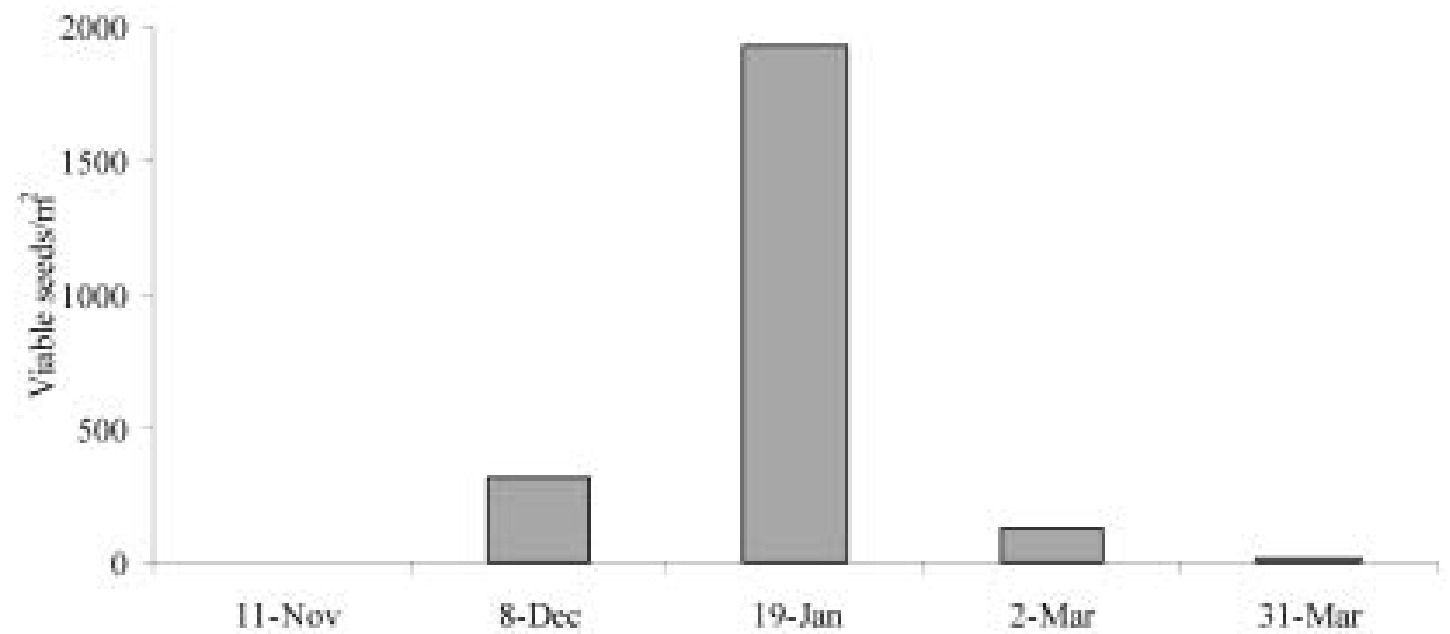

steadily to $1 \mathrm{seedhead} / \mathrm{m}^{2}$ by late March.

Although seedhead densities were high in November, none of the associated seed was viable (Figure 2). Viable seed was first detected in early December $(1$ seed/ seedhead), peaking in January (14 seeds per seedhead) with intermediate levels in March. Viable seed density (seedhead density $\mathrm{x}$ viable seed per seedhead) peaked in January, dropping sharply by early March (Figure 2). Endophyte infection of the viable seed was always 98 to $100 \%$.

Table 1 Estimated number of viable perennial ryegrass seeds eaten per cow per day (average of 4 days) while grazing high endophyte (90 to $100 \%$ of tillers infected) ryegrass pastures.

\begin{tabular}{lr}
\hline Period & Seeds/cow/day \\
\hline November 2000 & 0 \\
December 2000 & 42663 \\
January 2001 & 132864 \\
Early March 2001 & 16625 \\
Late March/early April 2001 & 1552 \\
\hline
\end{tabular}

Viable seed consumption per cow (Table 1) was estimated by combining seedhead removal data (pre minus post-grazing seedhead density) with the number of viable seeds per seedhead. As viable seed density increased, so did viable seed consumption per cow.

\section{Seed presence and germination in dung}

Ryegrass seed was always present in dung collected over the 3 days following the grazing of high endophyte ryegrass. Most of the seed was excreted in the first 24 hours. Seed was also observed in dung samples 4 days after grazing ryegrass in November, December and January, however, most of these seeds were damaged.

No ryegrass seed germinated in dung collected in
November and December. In January, March and April germination in dung was highest on the first day of quarantine, with the excretion of 953, 186 and 31 viable seeds per cow, respectively. This was equivalent to 97 , 86 and $100 \%$, respectively, of the total viable seed recovered per cow. Seedling germination in dung from the second day of quarantine ranged from 0 to 31 seedlings per cow, with no germination from samples collected on days 3 and 4.

About 990 viable ryegrass seeds were voided per cow in January after removal from ryegrass pastures. This is equivalent to $0.7 \%$ of the seed estimated to be eaten in one day. Comparable data for early March and early April were 1.3 and 2\%, respectively.

On average, $40 \%$ of seedlings germinating in dung deposited on the first day of quarantine contained endophyte. Dung deposited on the second day of quarantine contained one endophyte-free seedling in January, 1 endophyte-infected seedling in early March, and no seedlings in early April.

\section{Discussion}

\section{Timing of the quarantine period}

Ryegrass seed germinated in dung deposited from January to April, with peak levels in January. This contrasts with our earlier work (Burggraaf \& Thom 2000), when December deposited dung contained viable seed and peak germination was in late February-early March. Ryegrass seedhead development is affected by ambient temperature and cultivar (Langer 1980), and management differences with respect to grazing and nitrogen fertiliser application (L'Huillier \& Aislabie 1988; Langer 1980).

The lack of germination of seed in December dung samples (when low levels of viable seed were present on 
seedheads in the pasture) could have been influenced by selective cow grazing. Viable seed intakes were estimated by multiplying viable seed number per seedhead by the difference in seedhead density before and after grazing. However, grazing animals prefer green to dry, and young to old plant material (Arnold 1964), suggesting the cows may have grazed the green immature seedheads in preference to those containing viable seed. Seeds germinated in dung for all subsequent grazings, even with pre-grazing seedhead densities as low as 1 per $\mathrm{m}^{2}$. We suggest quarantine periods will be necessary from December until April to cope with variations in the timing of seedhead development.

\section{Quarantine duration}

Jones \& Simao Neto (1987) reported that the longer seed remains in the digestive tract of the animal, the greater the reduction in germination. In our experiment 86 to $100 \%$ of viable seed was recovered on the first day, and the remainder on the second day of quarantine. In an experiment where steers were fed tall fescue seed, the last viable seed was passed 84 hours after feeding (Shelby \& Schmidt 1991), in contrast to the rapid passage of viable seed in our experiment. Simao Neto $e t$ al. (1987) reported that plant species and the weight and age of the test animals can affect the passage of seed. Others (Shelby \& Schmidt 1991) noted that animal factors such as total feed intake, pregnancy and lactation, as well as increased fibre content of the feed and lower ambient temperature, reduced the mean retention time of seeds. In this trial, however, not all voided dung was collected, so low levels of viable seed may still have been present after 2 days.

In a sheep study, Jones \& Simao Neto (1987) found recovery time for $50 \%$ of the ingested seed in a high quality diet (in vitro digestibility $70 \%$ ) was $10-15$ hours shorter than for a low quality diet (in vitro digestibility $45 \%$ ). In vitro digestibility of Lotus corniculatus pastures on the same farm as our experiment was $80 \%$ in December 1997 (Harris et al. 1998). Thus extending the quarantine period from 2 to 3 days appears necessary to account for variation between animals and feed quality.

\section{Impact on pasture contamination}

Germination of ryegrass seed in dung is largely dependent on the availability of viable seedheads to graze, with peak germination in dung (950 seeds per cow) corresponding with peak viable seed densities in the paddocks grazed $\left(1900 / \mathrm{m}^{2}\right)$. In an experiment on the same farm the previous year, pre-grazing ryegrass seedhead densities under rotational grazing peaked at $261 / \mathrm{m}^{2}$, compared with $356 / \mathrm{m}^{2}$ in our experiment, and were significantly reduced by topping after grazing (160/ $\mathrm{m}^{2}$ ) (Bluett et al. 2001).
Approximately $0.8 \%$ of the viable seed eaten by cows was still viable after passing through the digestive tract, exceeding the estimate of $0.17 \%$ by Rolston et al. (2000) with sheep fed perennial ryegrass seed in metabolism crates. However, Simao Neto et al. (1987) reported that cattle have a higher percentage recovery of ingested seed than do sheep. This may be due to differences in the extent of chewing (Waldo 1973), and the larger particle size of digesta leaving the rumen in cattle (Poppi et al. 1985). Large variation may also occur between animals of the same species. Rolston et al. (2001) found a fivefold difference between sheep in the amount of perennial ryegrass seed still viable after passage through the digestive tract.

Viability of endophyte contained in the seeds after passage through the digestive tract is also an important factor affecting pasture contamination. Rolston et al. (2001) found that endophyte viability in perennial ryegrass seed was reduced from $80 \%$ to $18 \%$ after passage through sheep, and that endophyte viability was reduced faster than was seed viability. We noted similar changes in endophyte viability, falling from $100 \%$ infection before grazing to $40 \%$ in dung deposited in the first 24 hours after removal from the seed source. We found similar endophyte-infection levels (40\%) in ryegrass seedlings removed from cow dung pats in the field (van Vught \& Thom 1997).

This experiment estimated the output of viable ryegrass seeds in dung after ingestion by dairy cows, but did not monitor the survival of ryegrass seedlings germinating in dung. It has been speculated that the gap formed in the canopy and the increased nutrient concentration provided by dung pats may enhance the survival of seedlings that germinate in them (Shelby \& Schmidt 1991).

\section{Conclusions}

This trial has demonstrated the potential for endophyte contamination from ryegrass seed germinating in dung after passage through dairy cows. Although less than $1 \%$ of ingested ryegrass seed survived, and endophyte viability was reduced from 100 to $40 \%$, substantial contamination may still occur when ryegrass seedhead densities are high. It is difficult to accurately predict the impact of ingested seed on endophyte contamination because of variation between animals in seed intake and digestion, differences in pasture botanical composition, and different environmental conditions affecting seed germination and survival. Regular removal of green seedheads will reduce the risk of contamination from this source. The grazing of pastures containing ryegrass seedheads infected with the wild-type endophyte should be avoided for a minimum of 2 days before grazing endophyte-free pastures or those containing a new endophyte. 


\section{ACKNOWLEDGEMENTS}

We wish to thank Pat Laboyrie for grazing management, Lee Davis (AgResearch Ruakura) for seed germination and endophyte testing, and David Hume (AgResearch Grasslands) for advice on seedhead harvesting.

\section{REFERENCES}

Arnold, G.W. 1964. Factors within plant associations affecting the behaviour and performance of grazing animals. pp. 133-154. In: Grazing in terrestrial and marine environments. British Ecological Society Symposium No. 4.

Bluett, S.J.; Burggraaf, V.T.; Hume, D.E.; Tapper, B.A.; Thom, E.R. 2001. Establishment of ryegrass pastures containing a novel endophyte. Proceedings of the New Zealand Grassland Association 63: 259-265.

Burggraaf, V.T.; Thom, E.R. 2000. Contamination and persistence of endophyte-free pastures established by spray-drilling, and intensively grazed by dairy cows in the Waikato region of New Zealand. New Zealand Journal of Agricultural Research 43: 163-173.

Gallagher, R.T.; White, E.P.; Mortimer, P.H. 1981. Ryegrass staggers; isolation of potent neurotoxins lolitrem A and lolitrem B from staggers producing pastures. New Zealand Veterinary Journal 29: 189190.

Jones, R.M.; Simao Neto, M. 1987. Recovery of pasture seed ingested by ruminants. 3 . The effects of the amount of seed in the diet and of diet quality on seed recovery from sheep. Australian Journal of Experimental Agriculture 27: 253-256.

Harris, S.L.; Clark, D.A.; Laboyrie, P.J. 1998. Birdsfoot trefoil - an alternative legume for New Zealand dairy pastures. Proceedings of the New Zealand Grassland Association 60: 99-103.

Hill, N.S.; Hiatt, E.; Bouton, J. 1995. Development of monoclonal antibodies to Acremonium coenophialum. Tall fescue workshop, Nashville Tennessee; Southern Extension and Research Activity Information
Exchange Group-8. Vol. 1 p 16.

Langer, R.H.M. 1980. Growth of the grass plant in relation to seed production. Herbage seed production. Grassland Research and Practice Series 1: 6-11.

L'Huillier, P.J.; Aislabie, D.W. 1988. Natural reseeding in perennial ryegrass/white clover dairy pastures. Proceedings of the New Zealand Grassland Association 49: 111-115.

Marsh, R.; Campling, R.C. 1970. Fouling of pastures by dung. Herbage Abstracts 40: 123-130.

Poppi, D.P.; Hendricksen, R.E.; Minson, D.J. 1985. The relative resistance to escape of leaf and stem particles from the rumen of sheep and cattle. Journal of Agricultural Science, Cambridge 105: 9-14.

Prestidge, R.A.; Pottinger, R.P.; Barker, G.M. 1982: An association of Lolium endophyte with ryegrass resistance to Argentine stem weevil. Proceedings of the New Zealand Weed and Pest Control Conference 35: 119-122.

Rolston, M.P.; Fletcher, L.R.; Fletcher, C.G.; Archie, W.J. 2001. The viability of perennial ryegrass seed and its endophyte in sheep faeces. pp. 405-408. In: Proceedings of the $4^{\text {th }}$ International Neotyphodium/ Grass Interactions Symposium.

Shelby, R.A.; Schmidt, S.P. 1991. Survival of the tall fescue endophyte in the digestive tract of cattle and horses. Plant Disease 75: 776-778.

Simao Neto, M.; Jones, R.M.; Ratcliff, D. 1987. Recovery of pasture seed ingested by ruminants. 1 . Seed of six tropical pasture species fed to cattle, sheep and goats. Australian Journal of Experimental Agriculture 27: 239-246.

van Vught, V.T.; Thom, E.R. 1997. Ryegrass contamination of endophyte-free dairy pastures after spray-drilling in autumn. Proceedings of the New Zealand Grassland Association 59: 233-237.

Waldo, D.R. 1973. Extent and partition of cereal grain starch digestion in ruminants. Journal of Animal Science 37: 1062-1074. 